\title{
How fast can the European eel (Anguilla anguilla) larvae cross the Atlantic Ocean?
}

\author{
Sylvain Bonhommeau ${ }^{1,{ }^{*}}$, Bruno Blanke ${ }^{2}$, Anne-Marie Tréguier ${ }^{3}$, Nicolas Grima ${ }^{2}$, Etienne Rivot ${ }^{1}$, Youen \\ Vermard $^{1}$, Eric Greiner ${ }^{4}$ and Olivier Le Pape ${ }^{1}$

\begin{abstract}
${ }^{1}$ AGROCAMPUS OUEST, UMR 985 INRA-Agrocampus Ouest Ecologie et Santé des Ecosystèmes, Laboratoire d'Ecologie Halieutique, 65 rue de St-Brieuc, CS 84 215, 35042 Rennes cedex, France

${ }^{2}$ Laboratoire de Physique des Océans, CNRS-IFREMER-IRD-UBO, UFR Sciences et Techniques, 6 avenue Le Gorgeu - CS 93837, 29238 Brest CEDEX 3, France

${ }^{3}$ Laboratoire de Physique des Océans, CNRS-IFREMER-IRD-UBO, IFREMER, BP 70, 29280 Plouzané, France

${ }^{4}$ GIP Mercator-Ocean, Parc Technologique du Canal, 8-10 rue Hermes, 31526 Ramonville, France

*: Corresponding author : Sylvain Bonhommeau, email address : sylvain.bonhommeau@ifremer.fr
\end{abstract}

\begin{abstract}
:
The migration duration of European eel (Anguilla anguilla) larvae (leptocephali) from the spawning areas in the Sargasso Sea to the European continental shelf remains highly controversial, with estimates varying from 6 months to more than $2 \mathrm{yr}$. We estimated the fastest migration period and the shortest distance travelled by eel larvae by simulating Lagrangian particles released in the Sargasso Sea and by simulating a range of larval behaviours (fixed-depth drift, vertical diurnal migration and active-depth selection to maximize current velocity). This enabled us to compute (i) a passive drift speed, and (ii) a hypothetic swimming speed needed for European eel larvae to cross the Atlantic in 6 months (i.e., the migration duration estimated from otolith daily growth increments). Our results show that the minimum travel time for an eel larva that is passively drifting was 10 months and 3 days. Active behaviours (vertical diurnal migration and rheotaxis) paradoxically increased the migration period. We found that for leptocephali to cross the Atlantic Ocean in 6 months, they would need to swim a minimum of 3.4 body lengths per second for $8200 \mathrm{~km}$. No larvae have been observed with such swimming capabilities. These results provide evidence that leptocephali cannot cross the Atlantic in 6 months.
\end{abstract}

Keywords: Anguilla $\bullet$ fractals $•$ Gulf Stream $\bullet$ Lagrangian modelling $\bullet$ leptocephali $\bullet$ migration duration - Sargasso Sea 


\section{Introduction}

The European eel is a catadromous fish with an extremely long ocean migration route. Larvae are conveyed by warm ocean currents, more than $6,000 \mathrm{~km}$, from the the Sargasso Sea, in the east Atlantic, to the African and European shelf (from Mauritania to the Polar Circle (Schmidt, 1923)).

The current worldwide decline in eel populations has been well documented (Anonymous, 2003) and with its current low level of abundance, the European eel has been listed in the Appendix II of the Convention on Trade in Endangered Species of Wild Fauna and Flora (CITES, 2007). The decline in European eel population since the early 1980s is no doubt the combined effect of several interacting factors which are difficult to disentangle: anthropogenic activities such as overfishing (Dekker, 2004), habitat loss and degradation (McCleave, 2001; Feunteun, 2002; Palstra et al., 2006) and increasing stress in the freshwater stage due to parasites and diseases (e.g. Jørgensen et al., 1994; Aguilar et al., 2005; van Ginneken et al., 2005) and in the oceanic stage due to unfavourable oceanic conditions (Knights, 2003; Friedland et al., 2007; Bonhommeau et al., 2008).

The oceanic larval phase of European eels is of primary importance to understand eel ecology. There has been a long history of ecological studies dealing with marine life stages of this species (Dekker, 1998). As for most fish species, the major source of mortality occurs during the larval stage (Hjort, 1914). Moreover, this oceanic phase determines the dispersion over the coastal regions and the freshwater habitats. The migration duration is certainly one of the most critical and controversial features of the oceanic larva migration. The migration duration defines the age at which larvae settle as well as the spatial distribution of larvae as they arrive 
on European and African coasts. It also conditions our ability to understand how recruitment is linked to environmental fluctuations. This is critical in a context where major changes in oceanic conditions are known to impact fish populations (Beaugrand \& Reid, 2003; Lehodey et al., 2006). Eel recruitment data have been compared to environmental factors such as largescale oceanic and climate indices (Knights, 2003; Friedland et al., 2007; Bonhommeau et al., 2008; Kettle et al., 2008). Friedland et al. (2007) suggested that fluctuations in latitude of the $22.5^{\circ} \mathrm{C}$ isotherm, which is a useful proxy for the northern limit of eel spawning area, may be linked to fluctuations of retention processes within the Sargasso Sea gyre that affect both spawning location and transport of the leptocephali out of the Sargasso Sea. Kettle et al. (2008) showed a negative relationship between the state of the North Atlantic Oscillation (Hurrel, 1995) and glass eel catches in Europe. They suggested that this relationship might be linked to the larval survival in and migration from the Sargasso Sea spawning location. Primary production and sea temperature fluctuations in eel spawning area have also shown to be related to glass eel recruitment (Knights, 2003; Bonhommeau et al., 2008). All these studies used recruitment indices based on glass eel arrivals. Because oceanic environmental conditions are suspected to impact eel larvae several months before their arrival at the European shelf, linking environmental descriptors to glass eel recruitment necessitates a time lag to account for migration duration. Results still remain conditioned by the hypothesis made about migration duration, e.g. 1-year lag for Friedland et al. (2007) and 2.5 - 3 years for Knights (2003) and Bonhommeau et al. (2008).

Uncertainties about migration duration arise mainly from the difficulty in observing eel larvae during their oceanic stage. During the 70 years following the discovery of eel spawning locations (Schmidt, 1922, 1923), the migration duration of the European eel was speculated to be between 2 and 3 years. This assumption was grounded on growth curves of eel larvae. 
However, since the development of otolith microstructure analysis, estimates of the migration duration have changed. Sampling 423 eel larvae, from the Netherlands to Morocco, LecomteFiniger (1992) estimated that the migration duration (migration + metamorphosis into glass eels) took between 191 and 276 days (about 6 to 9 months), for glass eels caught in Portugal and UK respectively. Réveillac et al. (in prep) estimated a similar migration duration, i.e. 6-7 months (71-88 days for metamorphosis). Wang and Tzeng (2000) estimated the age of European glass eels vary between 14 and 16 months (98 days for metamorphosis). Arai et al. (2000) and Kuroki et al. (2008) found intermediate migration durations, with 7-9 months and 11 months (58 days for metamorphosis) respectively. Several assumptions were advanced to explain such short migration duration, such as an active and/or oriented migration hypothesis (Lecomte-Finiger, 1992, 1994). It has been shown how ocean general circulation models may provide insights to better grasp this trans-oceanic migration. Kettle \& Haines (2006) found using Lagrangian simulations, over a 4-year period (1993-1996), that the minimum migration duration of the European eel larvae is approximately 2 years.

Here we follow Kettle \& Haines (2006) and attempt to learn about the European eel's migration duration by performing Lagrangian simulations, our approach, however, differs from Kettle \& Haines (2006) in three ways. First, we do not investigate mean pathways and migration durations. Rather, we focus our analysis on the hypothesis testing: "Can eel larvae cross the Atlantic Ocean in 6 months?". To test this we focus on the fastest Lagrangian particles, drifting between the Sargasso Sea and the European shelf, to establish a minimum bound for the migration duration. Second, we use 2 different high-resolution general circulation models configurations: Drakkar and Mercator. Simulations were possible over a period of 45 years with the Drakkar model. The use of 2 different configurations enables us to compare results and test the accuracy of the Lagrangian simulations. Third, we relax the hypothesis of strict 
passive drift by testing different active, larval behaviours of vertical migration. Our simulations attempt to determine a minimum bound for the migration duration, across larval behaviours. Clearly, a very large number of different particle behaviours need to be tested in order to find the true minimum bound on migration duration, however, this is impossible in practice. Hence, we limit our analysis to three scenarios that are mostly designed to explore how an active behaviour of vertical migration may affect the migration duration: (i) particles drifting at fixed-depth as in Kettle \& Haines (2006), (ii) particles undergoing a vertical diurnal migration between $300 \mathrm{~m}$ and $50 \mathrm{~m}$ as observed in the wild (Castonguay and McCleave, 1987), (iii) particles drifting at the depth where the velocity of currents (whatever the direction) is the highest.

In so doing, we calculate the passive drift speed of the fastest particles. In addition, we address the questions of whether active behaviour enables particles to reach the European shelf faster. We also estimate the minimum swimming speed required for particles to cross the Atlantic Ocean in 6 months. 


\section{Materials and Methods}

\subsection{Circulation models}

Lagrangian simulations are performed using two different oceanic model configurations (hereafter Drakkar and Mercator). Both models are based on the NEMO/OPA (Nucleus for European Modelling of the Ocean / Océan Parallélisé) numerical code (Madec et al., 1998). In comparison with the model used by Kettle \& Haines (2006), these ocean general circulation models have better vertical resolution and longer integration periods.

Of the two models used, the Drakkar model (http://www.ifremer.fr/lpo/drakkar) covers the longest period (1958 to 2004), and allowed us to address the interannual variability of trajectories. The model configuration is global. It uses the ORCA025 grid (a tripolar grid with a 1/4 horizontal grid resolution at the equator). The configuration is described by Barnier et al. (2006) who showed its good performance in representing strong currents and eddy variability, even in comparison with higher resolution models. The water column is divided into 46 levels, with grid spacing ranging from $6 \mathrm{~m}$ near the surface to $250 \mathrm{~m}$ at the bottom. The simulation was run using atmospheric data (a blend of satellite products and ERA40 6-hourly winds, temperature and humidity). The Drakkar model is a fully prognostic model, which means that it does not use assimilation data (neither satellite altimetry nor in situ temperature or salinity), and therefore can be substantially far from observations in some areas. Fortunately those biases are less pronounced in the subtropical gyre, which is our region of interest, compared to the subpolar regions (Tréguier et al., 2005). For the purposes of our Atlantic analysis we used velocities only for the area ranging from -82 to $6^{\circ} \mathrm{E}$ and 10 to $60^{\circ} \mathrm{N}$. Since the observed depth of leptocephali is ranged from -50 and -300m (e.g. Castonguay \& McCleave, 1987), we reduced the oceanic model to the top 24 levels ( -3 to $-989 \mathrm{~m})$. To avoid the early spin-up phase of the model, we use the period 1960-2004 of the simulation. Circulation fields are time-mean 
archived every 5 days, which was the best possible compromise in terms of disk usage between the length of the simulation and the need for a fair sampling of the most energetic scales of variability present in the model.

The ocean velocity fields provided by the Mercator project (http://www.mercator-ocean.fr) were from the PSY1v2 analysis which covered the period 1992-2002 (the whole available period of this model). Velocity fields are archived every day. The horizontal grid resolution is $1 / 3^{\circ}$ at the equator. The geographical extension of this simulation is the Atlantic from $20^{\circ} \mathrm{S}$ to $70^{\circ} \mathrm{N}$. It encompasses 43 vertical levels from surface to $5000 \mathrm{~m}$ (the vertical resolution is from $12 \mathrm{~m}$ at the surface, to $200 \mathrm{~m}$ at the bottom). The model was forced by altimetry and in situ data that are fully described in the MERA-11 general scientific paper (Greiner et al., 2006). The area covered by the model has been reduced to -98 to $20^{\circ} \mathrm{E}$ to $20^{\circ} \mathrm{S}-70^{\circ} \mathrm{N}$ and the depth was limited to the first 16 levels $(-453 \mathrm{~m})$.

\subsection{Lagrangian simulation designs}

The study attempts to determine a minimum bound for the migration duration for particles drifting from the Sargasso Sea to the European shelf.

In all scenarios (defined hereafter as a combination of a model, Drakkar and Mercator, with one of the three behaviours tested for the particles), particles were released in the Sargasso Sea every 15 days (constrained by computational power) throughout the year. It is well known that the spawning season occurs during late winter and spring (e.g. McCleave et al. 1987) but particles were released throughout the year to explore the widest possible range of trajectories and increase the chance to approach the minimum bound for the migration duration.

Particles were tracked over a 1.5 year period, which is long enough to capture the fastest particle trajectory. We use the Ariane tool developed by B. Blanke and N. Grima, Laboratoire 
de Physique des Océans, CNRS-IFREMER-IRD-UBO, Brest, France, freely available at http://www.univ-brest.fr/lpo/ariane. This FORTRAN code is dedicated to the computation of 3D streamlines in a given velocity field (as the output of an Ocean General Circulation Model) and subsequent water mass analyses. The Ariane tool takes advantage of " $\mathrm{C}$ " grids used for horizontal discretization in numerical codes such as NEMO/OPA to analytically compute trajectories from model outputs. This algorithm calculates true trajectories for a given stationary velocity field. The Ariane tool has been used successfully in several studies to derive relevant information about basin-scale or global scale circulation patterns (e.g., Blanke \& Raynaud, 1997; Blanke et al., 1999; Blanke et al., 2001). Instead of analysing water masses (water particles) with the Ariane tool, we used it to track eel larvae defined here as a particle.

In the Drakkar configuration, drifters are released within each model grid cell, i.e. each $1 / 4^{\circ}$ and each 24 fixed-depth levels in an area enclosing the assumed spawning area of eels in the Sargasso Sea (Fig. 1). A total of 1972608 particles were thus released every two weeks, each year (one particle released every $0.25^{\circ}$ over the area bounded by $75^{\circ} \mathrm{W}$ to $50^{\circ} \mathrm{W}$ and from $22^{\circ} \mathrm{N}$ to $30^{\circ} \mathrm{N}$, for each of the 24 depth levels). To reduce simulation time, we restrict the whole available period (1958-2004) to three contrasting periods, defined by different states of the North Atlantic Oscillation (NAO; Hurrel, 1995). This provided an overview of different oceanic conditions. The Atlantic Ocean general circulation can be contrasted in terms of strength and/or latitude of the Gulf Stream (Taylor \& Stephens, 1998; Curry \& McCartney, 2001). Winter North Atlantic Oscillation is a good proxy to estimate the position and strength of the North Atlantic currents. Curry \& McCartney (2001) showed that the potential energy anomaly (i.e. the strength of the Gulf Stream) is well correlated to NAO. The same goes for the latitude of the Gulf Stream measured by the Gulf Stream index (Taylor \& Stephens, 1998). Kettle et al. (2008) showed that the migration of eel larvae may be linked to the NAO by a lar- 
val migration failure in the Sargasso Sea due to vertical density stratification and food restrictions. The selected periods were thus 1960-1964 (mean NAO Index = -1.7), 1973-1977 (0.9), and 1986-1999 (1.6). We then tested the relationships between arrival success, minimum migration duration and the NAO index.

Regarding the Mercator configuration, drifters are released at each model grid, i.e. each 1/3 degree and each 16 depth levels over the whole period available (1992-2002) in the same area as in the Drakkar model. A total of 691104 particles were released each year (one particle released every $1 / 3^{\circ}$ over the longitude from $75^{\circ} \mathrm{W}$ to $50^{\circ} \mathrm{W}$ and from $22^{\circ} \mathrm{N}$ to $30^{\circ} \mathrm{N}$, for each of the 16 depth levels and twice a month).

For both model configurations, three different particles behaviours were tested in Lagrangian simulations to explore how an active behaviour of vertical migration may affect the migration duration. We first assumed a fixed depth drift for all particles released at each vertical levels of the reduced model. This experiment corresponded to the hypothesis tested in Kettle \& Haines (2006). In a second experiment, a vertical diurnal migration was implemented. Particles flip every 12 hours from $-300 \mathrm{~m}$ to $-50 \mathrm{~m}$, as described in Castonguay \& McCleave (1987). This experiment mimics behaviour of eel larvae in the wild: leptocephalus collections have been shown to have a diurnal migration depending on their length (Castonguay \& McCleave, 1987). Until the length of $7 \mathrm{~mm}$, they are uniformly distributed over the $300 \mathrm{~m}$ upper layers (Schmidt, 1922; Schoth \& Tesch, 1983; Castonguay \& McCleave, 1987). When the larvae are larger, a diurnal vertical migration is observed from $-300 \mathrm{~m}$ in daytime and $-50 \mathrm{~m}$ at night (Schmidt, 1922; Castonguay \& McCleave, 1987; McCleave, 1993; McCleave et al., 1998). Although these different behaviours during the earliest life stages of eel leptocephali and afterwards have been observed, we chose to implement the daily flipping from $300 \mathrm{~m}$ to 
$50 \mathrm{~m}$ as soon as particles were released. In a third experiment, at each time step, particles flip from their current depth layer to the one with the fastest current speed, independent of the direction of the current. Although this active behaviour might appear has having only limited biological meaning, it is however grounded on the known positive rheotaxis behaviour of glass eels, a mechanism whereby they will turn to face into an oncoming current (Bertin, 1956; Bolliet et al., 2007). Here we assume that leptocephali may use the same ability to drift and choose the fastest currents. But it is worth noting that this third experiment remains mainly a way to explore a wider range of possible trajectories, to increase the chance to find a minimum bound for the migration duration. Clearly, a more optimal experiment would have consisted in covering all the possible particles trajectories corresponding to particles that could change depth randomly, but this optimal experiment revealed impossible to run in practice because of limits in computational power.

\subsection{Analysis}

Finishing line for the trajectories. Output files of Lagrangian simulations include position (longitude, latitude, depth) and time for each particle. Particles are considered as having "succeeded" in their migration when crossing the $20^{\circ} \mathrm{W}$ whatever the latitude. This finishing line is more eastward than the $25^{\circ} \mathrm{W}$ chosen by Kettle \& Haines (2006). Since the aim of the study is to estimate the migration duration of the fastest particle, the finishing line has to be as close as possible to the effective arrival area of eel larvae to compare to current estimates. However, $20^{\circ} \mathrm{W}$ is a reasonable limit since longitudes higher than $20^{\circ} \mathrm{W}$ correspond to continental slope that is not as well resolved by the physical model as the open ocean. Moreover, Lagrangian simulations are unable to represent tidal transport of eel larvae when they reach the shelves. Knowing the position and time of each particle, we calculate the distance covered by each 
particle reaching the finishing line and the migration duration. The mean drift speed $v_{i}$ for each particle i was estimated by the expression:

(1)

$$
v_{i}=\frac{d_{i}}{t_{i}}
$$

where $d_{i}$ is the distance covered by the particle $i$ that succeeded in crossing the $20^{\circ} \mathrm{W}$ and $t_{i}$ is the corresponding time taken to travel that distance.

Statistical analysis. To assess the impact of oceanic conditions on the migration duration and success, we analyse the link between the number of particles that succeeded in reaching the $20^{\circ} \mathrm{W}$ and the intensity of three large-scale oceanic indices averaged over the years of drift: the winter NAO (Hurrell, 1995), the Gulf Stream Index (GSI, Taylor \& Stephens, 1998), and the Potential Energy Anomalies (PEA, Curry \& McCartney, 2001). The correlations were checked after removing trends and autocorrelation from the time series. Indeed, procedures for statistical testing of the correlation between the series of oceanic indices and migration features must account for the autocorrelation and trends in the time series because they may result in an artificial increase in the statistical significance of the correlation test (Pyper and Peterman, 1998). We thus first-differenced the different time-series and then calculated the Pearson's correlation coefficient between the time-series as recommended in Pyper \& Peter$\operatorname{man}(1998)$.

Fractal dimension to characterise trajectories. In order to reach the shelf the most quickly, a particle has to be both in the fastest current and cover the shortest distance. When a particle drifts at a depth where the current velocity is the highest, particles with the most "linear" trajectory will cover the shortest distance and then have the shortest migration duration. For each trajectory, we used the fractal dimension as a synthetic index to characterise its linearity. The 
fractal dimension is a measure of how successive positions of particles fill the plane where they are. It characterises the drift, from linear (lower fractal dimension) to chaotic (higher fractal dimension). The fractal dimension was calculated with the function fdim from the package fdim (de Pison Ascacibar et al., 2007) of R Cran-project (R Development Core Team, 2007). 


\section{Results}

3.1 Simulations are consistent with previous knowledge

Results of Lagrangian simulations are consistent with observations of larval departure and arrivals areas. With the Drakkar model, after a migration duration of 1.5 years, the distribution of particles at $20^{\circ} \mathrm{W}$ is spread across 40 and $55^{\circ} \mathrm{N}$ with a peak at $50^{\circ} \mathrm{N}$ (Fig. 2a). Regarding the Mercator model, similar patterns are observed, but another peak appears in North Africa $\left(30-35^{\circ} \mathrm{N}\right)$ as found by Kettle \& Haines (2006) (Fig. 2b). The Drakkar model has a weak representation of the Azores Current, this explains the low proportion of particle arriving at Morocco.

Most arriving particles are seeded in the departure area located in the Western Sargasso Sea (75- $65^{\circ} \mathrm{W}$ and $22-30^{\circ} \mathrm{N}$; Fig. 3 for the Drakkar model). When arriving in the east Atlantic the depth range of particles crossing the $20^{\circ} \mathrm{W}$ ranges from $400 \mathrm{~m}$ to the surface, for both models (Fig. 4a and b). The shape of the distribution of these depths has a mode at $200 \mathrm{~m}$ depth, for both models, with another peak at $70 \mathrm{~m}$ depth for the Mercator model. The same patterns of departure and arrival areas were observed for the three experiments, i.e. fixed-depth, vertical migration, or fastest current choice. These general patterns correspond to the results of Kettle \& Haines (2006) and confirm the robustness of the results since the ocean models used do not have the same features as those used by Kettle \& Haines (2006).

3.2 Impact of large-scale oceanic indices and behaviours on migration success and duration

Results of this section have been summarised in Table 1 and 2.

\subsubsection{Factor influencing the migration success}


Large-scale oceanic indices. Over the whole simulation period, $0.0025 \%$ and $0.039 \%$ of those particles with a fixed depth drift, succeeded in crossing the $20^{\circ} \mathrm{W}$ in less than 1.5 years (Drakkar and Mercator model respectively). For both models, we found a significant positive relationship between winter NAO and the number of particles that succeed to arrive each year (Pearson's $\mathrm{r}=0.50$ and $0.78, \mathrm{p}=0.05$ and 0.04 , for Drakkar and Mercator respectively; autocorrelation removed following Pyper \& Peterman, 1998). The same goes for the Gulf Stream index $(\mathrm{r}=0.73$ and $0.80, \mathrm{p}=0.01$ and 0.04 for Drakkar and Mercator respectively) or the Potential Energy Anomalies $(r=0.57$ and $0.47, \mathrm{p}=0.05$ and 0.06 for Drakkar and Mercator respectively).

Influence of larvae behaviour. For the two models, the two active behaviours of particles tend to diminish the migration success. Over the simulation period, $0.0011 \%$ and $0.0004 \%$ of those particles, having a vertical diurnal migration, succeeded to cross the $20^{\circ} \mathrm{W}$ in less than 1.5 years (Drakkar and Mercator model respectively). When particles select the fastest current, the arrival success is still lower than the fixed depth experiment and similar to the vertical migration hypothesis one, i.e. $0.0014 \%$ and $0.0006 \%$ for Drakkar and Mercator model respectively.

\subsubsection{Estimates of the migration duration and its determining factors}

Regarding the Drakkar model, the fastest particle travelled, at a fixed depth, from the Sargasso Sea (initial position $27.5^{\circ} \mathrm{N}-74.5^{\circ} \mathrm{W}$ ) to the "finishing" line in 10 months and 19 days, covering $8447 \mathrm{~km}$. Fig. 5 indicates that the migration duration of the ten, hundred and thousand next particles is much greater than the fastest one. Regarding the Mercator model, the migration duration and the distance covered are very similar to Drakkar. The fastest particle travelled at fixed depth in 10 months and 3 days, and covered $8498 \mathrm{~km}$ (initial position $29.73^{\circ} \mathrm{N}-$ $\left.74.66^{\circ} \mathrm{W}\right)$. The duration of the ten, hundred, and thousand fastest particles represented in Fig. 
5 confirms results found with the Drakkar model, the fastest particle is significantly so. The migration routes of the ten fastest particles are similar for both models and are relatively direct (Fig. 6).

Large-scale oceanic indices influence minimum migration duration. The analysis of the relationships between NAO, GSI, and PEA and the minimum migration duration of particles drifting at fixed-depth reveals a negative link between NAO and minimum migration duration $(\mathrm{r}=-0.57, \mathrm{p}=0.04$ with autocorrelation removal). The same goes for GSI $(\mathrm{r}=-0.75, \mathrm{p}=0.01)$ and PEA $(\mathrm{r}=-0.48, \mathrm{p}=0.05)$. The minimum migration duration occurs for particles starting in 1990 (NAO over the drift equals 2.5 and high GSI and PEA). It indicates that when largescale indices are high (western winds paramount and high "strength" of the Gulf Stream) the minimum migration duration is lower. We can assume that the same goes for the migration duration overall. These results are therefore consistent with the positive correlation found between larval arrival success and large-scale oceanic indices. The faster the migration, the higher the arrival success.

Active behaviour slows down the migration and increases the distance. For both models, when implementing vertical diurnal migration behaviour, the fastest particle takes more than 5 months longer compared to fixed depth experiments and the distance covered is more than $3000 \mathrm{~km}$ longer. When having a vertical diurnal migration, the fastest particle travelled from the Sargasso Sea to the "finishing" line in 1 year, 3 months and 1 day, covering $9699 \mathrm{~km}$ (Drakkar model). For the Mercator model, the fastest particle travelled in 1 year, 2 months and 18 days, covering $8928 \mathrm{~km}$. It is the only particle that succeeded to reach the $20^{\circ} \mathrm{W}$ and it reached the $20^{\circ} \mathrm{W}$ at a longitude too far south to account for it in our study $\left(5.8^{\circ} \mathrm{N}\right.$, off the coast of Liberia) where no eels have been reported there (Schmidt, 1909a). The duration and 
distance obtained in the second active behaviour (i.e. particles actively shifting from depth layers to select the fastest current velocity) are very similar to the ones obtained in the vertical migration experiment. The fastest particle travelled from the Sargasso Sea to the finishing line in 1 year and 28 days and covered 9199km (Drakkar model). When using the Mercator model, 3 particles succeeded in reaching $20^{\circ} \mathrm{W}$. The fastest particle travelled $9748 \mathrm{~km}$ in 1 year, 2 months and 21 days. We did not account for the two other trajectories since they arrived too south to be realistic (North of Senegal and South of Mauritania).

To understand possible sources that lead to such discrepancies between fixed-depth experiments and active behaviour ones, we analysed the trajectories and physical conditions that particles encounter along their drift. Fig. 7 shows transects of zonal velocity (east-west) carried out at different trajectory locations of the fastest particle in the Drakkar model (Fig. 6). Fig. 7 shows that the zonal speed is negative (i.e. from East to West) when particles leave the Sargasso Sea and positive afterwards. Velocity transects highlight that the layer where the fastest particle drifts $(-94 \mathrm{~m})$ is most of the time the layer with the fastest velocity.

Fractal dimension analysis confirms that migration duration is closely associated with the linearity of the trajectories. The more linear the trajectory (the lower the fractal dimension D), the shorter the migration duration. For each depth, the fractal dimension of the trajectories of the fastest particle is represented in Fig. 8. The fractal dimension is the lowest for the depth $-94 m(D=0.88$; Drakkar model) and -132m $(\mathrm{D}=0.96$; Mercator model) (solid circles in Fig. 8). These depths correspond to the depths where the particles have the fastest migration duration as well. It confirms that the fastest particles have less wiggly trajectories. For these depths, the fractal dimension is close to one. In fractal theory a continuous line (i.e. an infinite 
number of points) typically has the value of unity. Here, the trajectory is close to a line but has a finite number of points. Hence the fractal dimension is just below one. 


\section{Discussion}

\subsection{Simulations fit with observations}

The general results regarding departure, arrival areas and the depth of drift are consistent with observations of leptocephali for both models. Most particles that succeeded in crossing the Atlantic in less than 1.5 years come from the Western Sargasso Sea. This is mainly due to the proximity to the Gulf Stream. Particles nearby can catch the Gulf Stream in less time than those more easterly spawned particles that drift in the low currents of the Sargasso Sea (Kleckner \& McCleave, 1982; see Fig. 7 panel A). The smallest larvae found in that area are also located in the Western part of the Sargasso Sea (see Fig. 2 in McCleave et al., 1987). The distribution area of particle arrivals fits well with the distribution area of the European eel (e.g. Schmidt, 1909a). This distribution is however mainly centred on West Europe at $20^{\circ} \mathrm{W}$ with another peak in North Africa for the Mercator model as found by Kettle \& Haines (2006). The Drakkar model has a weak representation of the Azores Current, this explains the lowest proportion of particle arriving at Morocco. Regarding the fixed depth experiment, the depth range $(50-400 \mathrm{~m})$ of particles crossing the $20^{\circ} \mathrm{W}$ in less than 1.5 years corresponds to the observed depths of leptocephali (e.g. Castonguay and McCleave, 1987) and to the study achieved by Kettle \& Haines (2006).

The positive relationships between oceanic indices such as the NAO, GSI (latitude of the Gulf Stream), and PEA (strength of the Gulf Stream) and the number of successful particles per year are consistent. It indicates that a larger number of particles reach $20 \mathrm{~W}$ when transport conditions were favourable (Kettle et al., 2008). These results are consistent with the negative link between oceanic indices and the minimum migration duration.

4.2 A minimum limit of the migration duration 
The potential influence of natural mortality. The aim of this study was not to estimate the mean migration duration of eel larvae but to investigate the minimum migration duration of a passive drifter from the Sargasso Sea to the European shelves. The estimation of the real mean migration duration by a Lagrangian model would require accounting for mortality. Indeed, the histogram of the migration duration of particles cannot be used to estimate the mean migration duration because accounting for mortality, which is thought to be roughly exponential with time, will drastically change the distribution of migration duration (Cowen et al., 2000 ; Hare et al., 2002). Particles with a long migration duration have a greater chance of mortality relative to particles with shorter migration duration. As eel larval mortality is still unknown, we prefer not to undertake such analysis and focus on the fastest particles. But it is noteworthy that accounting for mortality during the migration duration will necessarily lead to an equal or greater minimum bound for migration duration.

Drifting at fixed depth is the fastest way. The fastest particle is observed when drifting at fixed depths for the two models (94m for Drakkar and 132m for Mercator) and crosses the Atlantic Ocean in more than 10 months. The two conditions required to undergo the fastest migration are gathered: particles spend most of time in the fastest layer and the fractal dimension of their trajectories are the lowest. The hypothesis of an active vertical diurnal migration is the most realistic in term of eel ecology. Although less realistic, the behaviour consisting in selecting actively the depth layer with the higher current velocity at each time step was a valuable scenario to be tested as it increases the range of possible trajectories that are investigated. However, both these active behaviours lead to far higher migration duration and distance. In particular, the vertical migration in upper layers (higher fractal dimension) make the particles drift in eddies and hence increase the migration duration. Consequently, the diel migration behaviour of leptocephali is certainly not a way to maximize the use of the current velocity. 
Since leptocephali are planktonic feeders, the vertical migration could surely be driven by feeding needs and, overall, corresponds to the observed diurnal migration of plankton (e.g. Steinberg et al., 2002). It could be a way to avoid predators as well.

Interestingly enough, active behaviours lead particles to reach West Africa coast where no eels have hitherto been found except in Morocco. Since the aim of this paper was to find the shortest migration duration to reach European shelves, we could not account for these "misfit" particles. It is however interesting to note that this pathway is possible and eel larvae can reach the West African shelf with a reasonable migration duration. This result fits with Kettle \& Haines (2006) who found the same "hypothetic" pathways.

Potential sources of underestimation of the passive drift speed. Most successful particles start in the west of the release area (Fig. 3). This corresponds with the fast particles, but probably does not represent the area where most spawning occurs. This may be located in a more eastern areas. Drifting times, from the eastern spawning area to the Gulf Stream, is therefore neglected although it is known to be a region with slow currents (McCleave \& Kleckner, 1987).

We chose an arbitrary "finishing" line that is still far from the European shelf (1000 km from Ireland and $1500 \mathrm{~km}$ from France). This distance needs to be covered as well as the metamorphosis that is estimated to be occur over 18 to 52 days (Arai et al., 2000), 33 to 76 days (Lecomte-Finiger, 1992) or 98 days (Wang \& Tzeng, 2000). By removing these three steps, we have underestimated the migration duration. The migration duration from Lagrangian simulations corresponds to the estimated age of leptocephali before their metamorphosis on the continental slope (Schmidt, 1909b; McCleave, 1987; Antunes \& Tesch, 1997). The finishing line is before the continental slope. The drift duration to reach the $20^{\circ} \mathrm{W}$ is surely lower than the 
age before metamorphosis estimated by otolith microstructure since a long distance remains to be covered until the continental slope.

We used off-line computations whereas ideally we would use online computations, using the computed velocity at each model time step to integrate trajectories. Working with averaged quantities (the archived fields of a simulation) can introduce biases in trajectory calculations. As opposed to that, offline calculations, like those used in this study, offer much more flexibility and discernment in the definition of the Lagrangian experiments, without the cost of running again a full ocean model. Our study deals with models with horizontal grids between eddy permitting and fully eddy resolving resolution. Furthermore, the Drakkar model uses airsea fluxes that rely on the $\sim 1^{\circ}$ (at the equator) ERA-40 6-hourly atmospheric reanalysis. The Mercator simulation makes use of equivalent re-analyses of surface atmospheric variables, but was run at $1 / 3^{\circ}$ resolution that puts it more on the "eddy-permitting" side. As a matter of fact, for both models, the intrinsic scales of variability are long enough to be fairly well sampled with a 5-day and appropriately sampled with a 1-day archiving strategy for the Drakkar model and the Mercator model, respectively. In other respects, one must not forget that the Drakkar simulation has the unique advantage of being long enough to address interannual (or even interdecadal) variability, of course to the detriment of the sharpness of the time sampling of its archive. As already shown by McClean et al. (2002), a change in model resolution goes with significant change in the characteristic length scales associated with the movement of numerical drifters: Lagrangian integral time scales of the order of a few days, typical of genuinely observed drifter displacements in the North Atlantic, can only be recovered with high-resolution modelling, whereas coarser models tend to overestimate such quantities (just as the two simulations we have used). Such conclusions lend confidence to our analysis run using 5-day 
model outputs for the Drakkar simulation and encourage us to favour a more frequent (daily) storage when dealing with much finer horizontal resolution.

Indeed, using ocean general circulation models that do not fully resolve mesoscale eddies, we underestimate the distance covered by particles and / or overestimate the drift speed. The Drakkar and Mercator models are among the most precise models currently running to model ocean circulation with a resolution of $1 / 4^{\circ}$ and $1 / 3^{\circ}$ respectively. It would be interesting to assess the impact of the use of higher resolution models on the speed and the distance covered by particles. When using Drakkar (the best resolution of the two models), the migration duration is slightly longer than with Mercator. This phenomenon is highlighted in Fig. 5. The use of higher resolution models (for instance $1 / 12^{\circ}$ ) would have enabled us to solve mesoscale eddies more accurately (Smith et al., 2000). When improving the resolution of ocean general circulation model, two combined effects could be observed. First, the maximal speed is higher but second, particles have longer trajectories since they can be trapped in mesoscale eddies. Further studies may analyse possible consequences of the use of higher resolution model on the migration duration.

4.3 In order to reach European shelves do leptocephali swim?

Our results clearly contrast with the analysis of otolith microstructure (e.g. Lecomte-Finiger, 1992). When considering the migration duration inferred from otolith microstructure, eel larvae would be able to reach European coasts in 6 months. In contrast, our estimates of a minimum bound for migration duration is about 10 months. Here we try to discuss our results with regards to results of otolith analyses. First, it should be noted that results of otolith analyses remain questionable (McCleave, 2008). The reading accuracy of daily growth increments has sparked a large debate (e.g. Antunes \& Tesch, 1997; McCleave et al., 1998). To our 
knowledge, the age estimation of eel larvae from daily increment has never been validated for the European eel. Leptocephali may have such a low metabolic rate that increments in otoliths might not be deposited daily, or be deposited daily but be too thin to be observed in Scanning Electron Microscopy. We refer to Bonhommeau et al. (submitted) for a complete description of possible source of misinterpretation of otolith microstructure. Second, it is interesting to question the implications of such short migration duration (6 months) in terms of swimming speed. Using the drift distance and migration of the fastest particle in the Drakkar model, the mean passive drift speed (Eq. 1) is $30.2{\mathrm{~cm} . \mathrm{s}^{-}}^{1}$. The required speed to cover the same distance in 6 months is $8447 \mathrm{~km} / 6$ months $=54.3 \mathrm{~cm} \cdot \mathrm{s}^{-}$that would be possible with an active swimming speed of $54.3-30.2=24.1{\mathrm{~cm} . \mathrm{s}^{-}}^{1}$. Regarding the Mercator model, the mean passive drift speed of the fastest particle is $32.0 \mathrm{~cm} . \mathrm{s}^{-}{ }^{1}$. Using the same calculation, the required speed to cover the $8498 \mathrm{~km}$ in 6 months is $54.6 \mathrm{~cm} . s-^{-1}$, leading to a required active swimming speed of $22.6 \mathrm{~cm} \mathrm{~s}^{-}{ }^{1}$. Arai et al. (2000) estimated that the age at metamorphosis may be higher than those found by Lecomte-Finiger $(1992,1994)$, that is a mean age of 198 days. In that case, the required speed would be $19.2 \mathrm{~cm} . \mathrm{s}^{-1}$ and $17.7 \mathrm{~cm} . \mathrm{s}^{-1}$ for the Drakkar and Mercator model respectively. Our approach then suggests that such a short migration would require an active swimming around 18-24 cm.s- ${ }^{1}$. This means that leptocephali should swim at least at 3.4 body lengths. $\mathrm{s}^{-1}$ (of a fully-developed leptocephali which is about $70 \mathrm{~mm}$, Schmidt, 1922, 1923) over more than $8400 \mathrm{~km}$ (the distance made by the fastest particle; Fig. 5). It is noteworthy that particles that have a longer passive drift will have to have a faster swimming speed. It is also noteworthy that this hypothetical swimming speed assumes a perfect orientation of leptocephali and this has not been demonstrated. Also, the ten fastest particles follow direct routes (Fig. 6a-b) and even an active oriented swimming would not have enabled them to reach the European shelf more directly. 
The hypothesis of active and oriented swimming, asserted to make possible the 6-month migration duration of eel larvae, appears spurious with regards to the present results. Indeed, although such swimming speeds are observed for migrating adult fish (Blaxter, 1969), energy expenditure required seems unrealistic for eel larvae since the open ocean is a low productive area (Raven et al., 2007). Moreover, swimming activity would need developed muscles but McCleave et al. (1998) described that: "leptocephali [...] have only minute amounts of subcutaneous red muscle (Leonard \& Summers, 1976)".

\section{Conclusion}

We have investigated the minimum migration duration of passive particles as they drift from the Sargasso Sea to the European shelf. In order to do this we used high-resolution ocean general circulation models. By contrast to Kettle \& Haines (2006), we examined the possible influences of active behaviour of particles (vertical diurnal migration and faster current choice) on migration duration. We showed that active behaviours are not a way to minimize the migration duration but, on the contrary, increase the migration duration. Our results show that very few particles reach the $20^{\circ} \mathrm{W}$ in less than 1 year ( 1 over several millions) and the crossing in 6 months, thanks to an active and oriented swimming ,would require a very fast swimming speed (more than 3.4 body length per second) over a very long distance (more than $8000 \mathrm{~km}$ ). Such energy expenditure is not possible in low productive areas such as open ocean. We do not reconsider the swimming ability of leptocephali (e.g. Bishop and Torres, 1999), but this swimming capacity could not be used to reach European shelf significantly faster than with the passive drift. 


\section{Acknowledgments}

We thank Gaëtan Vinay the GIP Mercator Ocean (Toulouse, France) for providing the Mercator circulation fields (PSY1v2) and Jean-Marc Molines (CNRS, LEGI, Grenoble) who provided the Drakkar model simulation. The Drakkar model has been run at the IDRIS computing centre of CNRS, Orsay, France. We thank Roger Le Du for the orthodromic distance calculation. We thank James Watson for English improvements and suggestions. We thank James McCleave and Karen Edwards and one other anonymous referee for their in-depth review and helpful comments. 


\section{References}

Aguilar, A., Alvarez, M.F., Leiro, J.M. \& Sanmartin, M.L. (2005). Parasite populations of the European eel (Anguilla anguilla L.) in the Rivers Ulla and Tea (Galicia, northwest Spain). Aquaculture 249:85-94.

Anonymous (2003). Worldwide decline of eel resources necessitates immediate action Québec declaration of concern. Fisheries 28:28-30.

Antunes, C. \& Tesch, F.-W. (1997). A critical consideration of the metamorphosis zone when identifying daily rings in otoliths of European eel, Anguilla anguilla (L). Ecol. Freshw. Fish 6:102-107.

Arai, T., Otake, T. \& Tsukamoto, K. (2000). Timing of metamorphosis and larval segregation

of the Atlantic eels Anguilla rostrata and A. anguilla, as revealed by otolith microstructure and microchemistry. Mar. Biol. 137:39-45.

Barnier, B., Madec, G., Penduff, T., Molines, J.M., Tréguier, A.-M., Le Sommer, J., Beckmann, A., Biastoch, A., Boening, C., Dengg, J., Derval, C., Durand, E., Gulev, S., Remy, E., Talandier, C., Theetten, S., Maltrud, M., McClean, J. \& DeCuevas, B. (2006). Impact of partial steps and momentum advection schemes in a global ocean circulation model at eddy permitting resolution. Ocean Dyn. 56:543-567.

Beaugrand, G. \& Reid, P.C. (2003). Long-term changes in phytoplankton, zooplankton and salmon related to climate. Glob. Change Biol. 9:801-817.

Bertin, L. (1956). Eels, a biological study. Cleaver-Hume Press Ltd, London. 
Bishop, R. E. \& Torres, J. J. (1999). Leptocephalus energetics: Metabolism and excretion. J. Exp. Biol. 202:2485-2493.

Blanke, B. \& Raynaud, S. (1997) Kinematics of the Pacific Equatoial Undercurrent: a Eulerian and Lagrangian approach from GCM results. J. Phys. Oceanogr. 27:1038-1053.

Blanke, B., Arhan, M., Madec, G. \& Roche, S. (1999) Warm water paths in the equatorial Atlantic as diagnosed with general circulation model. J. Phys. Oceanogr. 27:1038-1053.

Blanke, B., Speich, S., Madec, G. \& Döös, K. (2001) A global diagnostic of interocean mass transfers. J. Phys. Oceanogr. 31:1623-1632.

Blaxter, J.H.S. (1969). Swimming speed of fish. Tech. rept. Fish. Rep. 62, 69-100. FAO.

Bolliet, V., Lambert, P., Rives, J. \& Bardonnet, A. (2007). Rhythmic swimming activity in Anguilla anguilla glass eels: Synchronisation to water current reversal under laboratory conditions. J. Exp. Mar. Biol. Ecol. 344:54-66.

Bonhommeau, S., Chassot, E. \& Rivot, E. (2008). Fluctuation in European eel (Anguilla anguilla) recruitment resulting from environmental changes in the Sargasso Sea. Fish. Oceanogr. 17:32-44.

Bonhommeau, S., Castonguay, M., Rivot, E., Sabatié, R. \& Le Pape, O. (submitted). The oceanic life and migration duration of American and European eel larvae. Fish Fish..

Castonguay, M. \& McCleave, J.D. (1987). Vertical distributions, diel and ontogenic vertical migrations and net avoidance of leptocephali of Anguilla and other common species in the Sargasso Sea. J. Plankton Res. 9:195-214. 
CITES (2007). Additional information concerning proposal cop14 prop. 18 on the European eel (Anguilla anguilla). vol. CoP14 Inf. 21. Convention on International Trade in Endangered Species of Wild Fauna and Flora (www.cites.org/common/cop/14/inf/E14i-21.pdf).

Curry, R.G. \& McCartney, M.S. (2001). Ocean gyre circulation changes associated with the North Atlantic Oscillation. J. Phys. Oceanogr. 31:3374-3400.

de Pison Ascacibar, Fco. J. M., Mere, J. O., Limas, M. C. \& de Cos Juez, Fco. J. 2007. fdim: Functions for calculating fractal dimension. R package version 1.0-5.

Dekker, W. (1998). Long-term trends in the glasseels immigrating at Den Oever, the Netherlands. Bull. Fr. Pech. Piscic. 349:199-214.

Dekker, W. (2004). What caused the decline of the Lake IJsselmeer eel stock after 1960? ICES J. Mar. Sci. 61:394-404.

Feunteun, E. (2002). Management and restoration of European eel population (Anguilla anguilla): An impossible bargain. Ecol. Eng. 18:575-591.

Friedland, K.D., Miller, M.J. \& Knights, B. (2007). Oceanic changes in the Sargasso Sea and declines in recruitment of the European eel. ICES J. Mar. Sci. 64:519-530.

Greiner, E., Benkiran, M., Blayo, E. \& Dibarboure, G. (2006). MERA-11 general scientific paper, 1992-2002 PSY1V2 reanalysis. Tech. rept. reference MOO-MR-431-37-MER. Mercator-Ocean, 8-10 rue Hermès, 31520 Ramonville St. Agne, France.

Hjort, J. (1914). Fluctuations in the great fisheries of Northern Europe. Rapp. Proc. ver. Con. Int. Exp. Mer 20:1-228. 
Hurrell, J. W. (1995). Decadal trends in the North-Atlantic Oscillation - Regional temperatures and precipitation. Science 269:676-679.

Jørgensen, P.E.V., Castric, J., Hill, B., Ljungberg, O. \& Dekinkelin, P. 1994. The occurrence of virus-infections in elvers and eels (Anguilla anguilla) in Europe with particular reference to VHSV and IHNV. Aquaculture 123:11-19.

Kettle, A. J. \& Haines, K. (2006). How does the European eel (Anguilla anguilla) retain its population structure during its larval migration across the North Atlantic Ocean? Can. J. Fish. Aquat. Sci. 63:90-106.

Kettle, A.J., Bakker, D.C.E. \& Haines, K. (2008). Impact of the North Atlantic Oscillation on the trans-Atlantic migrations of the European eel (Anguilla anguilla). J. Geophys. Res. Ocean., 113, GE03004, doi:10.1029/2007JG000589.

Kleckner, R.C. \& McCleave, J.D. (1982). Entry of migrating American eel leptocephali into the Gulf Stream system. Helgoland Mar. Res. 35:329-339.

Knights, B. (2003). A review of the possible impacts of long-term oceanic and climate changes and fishing mortality on recruitment of anguillid eels of the Northern Hemisphere. Sci. Total Environ. 310:237-244.

Kuroki, M., Momoko, K., Jónsson, B., Aoyama, J., Miller, M.J., Naokes, D.L.G. \& Tsukamoto, K. (2008) Inshore migration and otolith microstructure/microchemistry of anguillid glass eels recruited to Iceland. Environ. Biol. Fish 83:309-325. 
Lecomte-Finiger, R. (1992). Growth history and age at recruitment of European glass eels (Anguilla anguilla) as revealed by otolith microstructure. Mar. Biol. 114:205-210.

Lecomte-Finiger, R. (1994). The early-life of the European Eel. Nature 370:424.

Lehodey, P., Alheit, J., Barange, M., Baumgartner, T., Beaugrand, G., Drinkwater, K., Fromentin, J.-M, Hare, S.H., Ottersen G., Perry, R.I., Roy, C., van der Lingen, C.D. \& Wernerl, F. (2006). Climate Variability, Fish, and Fisheries. J. Clim. 19:5009- 5030.

Leonard, J.B. \& Summers, R.G. (1976). The ultrastructure of the integument of the American eel, Anguilla rostrata. Cell Tissue Res. 171:1-30.

Madec, G., Delecluse, P., Imbard, M. \& Levy, C. (1998). OPA 8.1 general circulation model reference manual. Notes de l'IPSL 11. Université P. et M. Curie, Paris, France.

McClean, J, Poulain, P \& Pelton J.W. (2002). Eulerian and Lagrangian statistics from surface drifters and a high-resolution POP simulation in the North Atlantic. J. Phys. Oceanogr. 32: $2472-2491$

McCleave, J.D. (1987). Migration of Anguilla in the ocean signposts for adults! Signposts for leptocephali? In: Herrnkind, W.F., \& Thistle, A.B. (eds), Signposts in the sea: Proceedings of a multidisciplinary workshop on marine animal orientation and migration. held 29-31 may 1986 at the Florida State University Conference Center, Tallahassee, Florida.

McCleave, J.D. (1993). Physical and behavioral controls on the oceanic distribution and migration of leptocephali. J. Fish Biol. 43:243-273. 
McCleave, J.D. (2001). Simulation of the impact of dams and fishing weirs on reproductive potential of silver-phase American eels in the Kennebec River basin, Maine. North Am. J. Fish Manage. 21:592-605.

McCleave, J.D. (2008) Contrasts between spawning times of Anguilla species estimated from larval sampling at sea and from otolith analysis of recruiting glass eels. Mar. Biol. 155:249262.

McCleave, J.D. \& Kleckner, R.C. (1987). Distribution of leptocephali of the catadromous Anguilla species in the Western Sargasso Sea in relation to water circulation and migration. Bull. Mar. Sci. 41:789-806.

McCleave, J.D., Kleckner, R.C., \& Castonguay, M. (1987). Reproductive sympatry of American and European eels and implications for migration and taxonomy. Am. Fish. Soc. Symp., 1: 286-297.

McCleave, J.D., Brickley, P.J., O'Brien, K.M., Kistner, D.A., Wong, M.W., Gallagher, M. \& Watson, S.M. (1998). Do leptocephali of the European eel swim to reach continental waters? Status of the question. J. Mar. Biol. Assoc. U.K. 78:285-306.

Nishi, T. \& Kawamura, G. (2005). Anguilla japonica is already magnetiosensitive at the glass eel phase. J. Fish Biol. 67:1213-1224.

Palstra, A.P., van Ginneken, V.J.T., Murk, A.J. \& van den Thillart, G.E.E.J.M. (2006). Are dioxin-like contaminants responsible for the eel (Anguilla anguilla) drama? Naturwissenschaften 93:145-148. 
Pyper, B.J. \& Peterman, R.M. (1998). Comparison of methods to account for autocorrelation in correlation analyses of fish data. Can. J. Fish. Aquat. Sci. 55:2127-2140.

R Development Core Team. (2007). R: A Language and Environment for Statistical Computing. R Foundation for Statistical Computing, Vienna, Austria.

Raven, P.H., Johnson, G.B. \& Losos, J.B.S.S.R. (2007). Biologie. $7^{\text {th }}$ edn. De Boeck.

Réveillac, E., Lecomte-Finiger, R. \& Feunteun, E. (in prep.) Larval dispersal of the European eel (Anguilla anguilla) as revealed by spatio temporal variability of early life histories and biometrics characteristics at recruitment.

Schmidt, J. (1909)a. On the distribution of the fresh-water eels (Anguilla) throughout the world. I. Atlantic Ocean and adjacent regions. Meddelelser fra Kommissionen for Havundersögelser, Seri Fiskeri III:1-45.

Schmidt, J. (1909)b. Remarks on the metamorphosis and distribution of the larvae of the eel (Anguilla vulgaris Turt.). Meddelelser fra Kommissionen for Havundersögelser, Seri Fiskeri III:1-17.

Schmidt, J. (1922). The breeding places of the eels. Philos. Trans. R. Soc. B-Biol. Sci. 211:179-208.

Schmidt, J. (1923). Breeding places and migrations of the Eel. Nature 111:51-54.

Schoth, M. \& Tesch, F.-W. (1983). Remarks on the vertical distribution of leptocephali in the Sargasso Sea with special reference to 0-group Anguilla larvae. ICES CM/M:7, 19 p. 
Smith, R. D., Maltrud, M. E., Bryan, F. O. \& Hecht, M. W. (2000). Numerical simulation of the North Atlantic Ocean at 1/10 degrees. J. Phys. Oceanogr. 30:1532-1561.

Steinberg, D. K., Goldthwait, S. A. \& Hansell, D. A. (2002). Zooplankton vertical migration and the active transport of dissolved organic and inorganic nitrogen in the Sargasso Sea. Deep-Sea Res. Part I 49:1445-1461.

Taylor, A.H. \& Stephens, J.A. (1998). The North Atlantic oscillation and the latitude of the Gulf Stream. Tellus Ser. A 50:134-142.

Tesch, F.-W., Niermann, U. \& Plaga, A. (1986). Differences in development stage and stock density of larval Anguilla anguilla off the west coast of Europe. Vie et Milieu 36:255-260.

Tréguier, A.-M., Theetten, S., Chassignet, E., Penduff, T., Smith, R., Talley, L., Beismann, J.O. \& Böning, C. (2005). The North Atlantic subpolar gyre in four high-resolution models. J. Phys. Oceanogr. 35:757-774.

Turnpenny, A.W.H. (1983). Swimming performance of juvenile sprat, Sprattus sprattus L. and herring, Clupea harengus L., at different salinities. J. Fish Biol. 23:321-325.

van Ginneken, V., Ballieux, B., Willemze, R., Coldenhoff, K., Lentjes, E., Antonissen, E., Haenen, O. \& van den Thillart, G. (2005). Hematology patterns of migrating European eels and the role of EVEX virus. Comp. Biochem. Physiol. C 140:97-102.

Wang, C.H. \& Tzeng, W.N. (2000). The timing of metamorphosis and growth rates of American and European eel leptocephali: A mechanism of larval segregative migration. Fish Res. 46:191-205. 
Table 1: Number of particles released and succeeding in crossing the $20^{\circ} \mathrm{W}$ line, minimum migration duration and distance covered for the fastest particles for the two ocean configurations (Drakkar and Mercator) and the three behaviours (fixed-depth, vertical diurnal migration and fastest current choice).

\begin{tabular}{|c|c|c|c|c|c|}
\hline $\begin{array}{c}\text { Ocean configura- } \\
\text { tion }\end{array}$ & Behaviour & $\begin{array}{l}\text { \# of particles } \\
\text { released over } \\
\text { the whole peri- } \\
\text { od }\end{array}$ & $\begin{array}{l}\# \text { of particles } \\
\text { succeeding in } \\
\text { crossing the } \\
20^{\circ} \mathrm{W} \text { (as a } \% \\
\text { of released) }\end{array}$ & $\begin{array}{c}\text { Minimum } \\
\text { migration } \\
\text { duration }\end{array}$ & $\begin{array}{l}\text { Distance } \\
\text { covered }\end{array}$ \\
\hline \multirow{3}{*}{ Drakkar } & Fixed-depth & 47342592 & $0.0025 \%$ & $\begin{array}{r}10 \text { months } \\
19 \text { days }\end{array}$ & $8447 \mathrm{~km}$ \\
\hline & $\begin{array}{l}\text { Vertical mi- } \\
\text { gration }\end{array}$ & 1972608 & $0.0011 \%$ & $\begin{array}{r}1 \text { year } \\
3 \text { months } \\
1 \text { day }\end{array}$ & $9699 \mathrm{~km}$ \\
\hline & $\begin{array}{l}\text { Fastest cur- } \\
\text { rent choice }\end{array}$ & 1972608 & $0.0014 \%$ & $\begin{array}{l}1 \text { year } \\
28 \text { days }\end{array}$ & $9199 \mathrm{~km}$ \\
\hline \multirow{3}{*}{ Mercator } & Fixed-depth & 7602144 & $0.039 \%$ & $\begin{array}{r}10 \text { months } \\
3 \text { days }\end{array}$ & $8498 \mathrm{~km}$ \\
\hline & $\begin{array}{l}\text { Vertical mi- } \\
\text { gration }\end{array}$ & 475200 & $0.0004 \%$ & $\begin{array}{r}1 \text { year } \\
2 \text { months } \\
18 \text { days }\end{array}$ & $8928 \mathrm{~km}$ \\
\hline & $\begin{array}{l}\text { Fastest cur- } \\
\text { rent choice }\end{array}$ & 475200 & $0.0006 \%$ & $\begin{array}{r}1 \text { year } \\
2 \text { months } \\
21 \text { days }\end{array}$ & $9748 \mathrm{~km}$ \\
\hline
\end{tabular}


Table 2: Summary of relationships between the three large-scale oceanic indices (North Atlantic Oscillation (NAO; Hurrel, 1995), Gulf Stream Index (GSI; Taylor \& Stephens, 1998), Potential Energy Anomaly (PEA; Curry \& McCartney, 2001)) and the arrival success and the minimum migration duration for each simulated years with the Drakkar and Mercator configurations (using the fixed-depth experiment). $\mathrm{r}$ is the Pearson's correlation coefficient and $\mathrm{p}$, the significance level (n.s. stands for non significant).

\begin{tabular}{cccccccc}
\hline $\begin{array}{c}\text { Ocean configura- } \\
\text { tion }\end{array}$ & $\begin{array}{c}\text { Lagrangian out- } \\
\text { put tested }\end{array}$ & \multicolumn{2}{c}{ NAO } & \multicolumn{2}{c}{ GSI } & \multicolumn{3}{c}{ PEA } \\
\cline { 3 - 8 } Drakkar & $\begin{array}{c}\text { Minimum dura- } \\
\text { tion }\end{array}$ & -0.57 & 0.04 & -0.75 & 0.01 & -0.48 & 0.05 \\
& Arrival success & 0.5 & 0.05 & 0.73 & 0.01 & 0.57 & 0.05 \\
\hline \multirow{2}{*}{ Mercator } & $\begin{array}{c}\text { Minimum dura- } \\
\text { tion }\end{array}$ & -0.40 & n.s. & -0.54 & 0.07 & -0.32 & n.s. \\
& Arrival success & 0.78 & 0.04 & 0.80 & 0.04 & 0.47 & n.s \\
\hline
\end{tabular}




\section{Figure Captions}

Figure 1. Map of the initial positions for the Lagrangian simulations using the Mercator model (i.e. each $1 / 3^{\circ}$ ). The European eel spawning area is charted out by a black polygon (from Fig. 2 in McCleave et al., 1987). The initial positions using the Drakkar model have the same boundaries than Mercator but are set each $1 / 4^{\circ}$.

Figure 2. Latitude distribution of particles successfully crossing the $20^{\circ} \mathrm{W}$ meridian. Particles drift over 1.5 years after being released within the eel spawning area for the Drakkar (a) and Mercator (b) models. The maps on the right hand side are drawn up until the $20^{\circ} \mathrm{W}$ where particles are counted. They show the location of the latitude bins defining the histogram.

Figure 3: Number of successful particles as a function of starting location in the Sargasso Sea when using the Drakkar model (colour scale). The European eel spawning area is charted out by a black polygon.

Figure 4. Depth distributions of the particles successfully crossing the $20^{\circ} \mathrm{W}$ meridian within 1.5 years after being released within the eel spawning area and drifting at fixed-depth for the Drakkar (a) Mercator (b) model.

Figure 5. Boxplot of migration duration of the fastest particle, the ten fastest particles, the hundred fastest particles, and the thousand fastest particles for Drakkar model (white) and Mercator model (gray). Circles represent individuals outside the confidence interval. 
Figure 6. Trajectories of the ten fastest particles that succeeded to cross the $20^{\circ} \mathrm{W}$ using the Drakkar model (a) and Mercator model (b). The letters (A,B,C,D,E,F) represent the positions used to calculate the diagram of zonal velocity at different depths (used in Fig. 7).

Figure 7. Diagrams of the zonal speed u (West - East) at different depths at positions (described in Fig. 6) of the fastest particle using the Drakkar model. The horizontal dashed lines represents the depth of the fastest particle $(94 \mathrm{~m})$ found when running on the Drakkar model.

Figure 8. Fractal dimensions of the trajectory of the fastest particle in each depth of the Drakkar model (solid line) and the Mercator model (dashed line). The solid circle represents the depth of drift of the fastest particle in each model. 
Figure 1

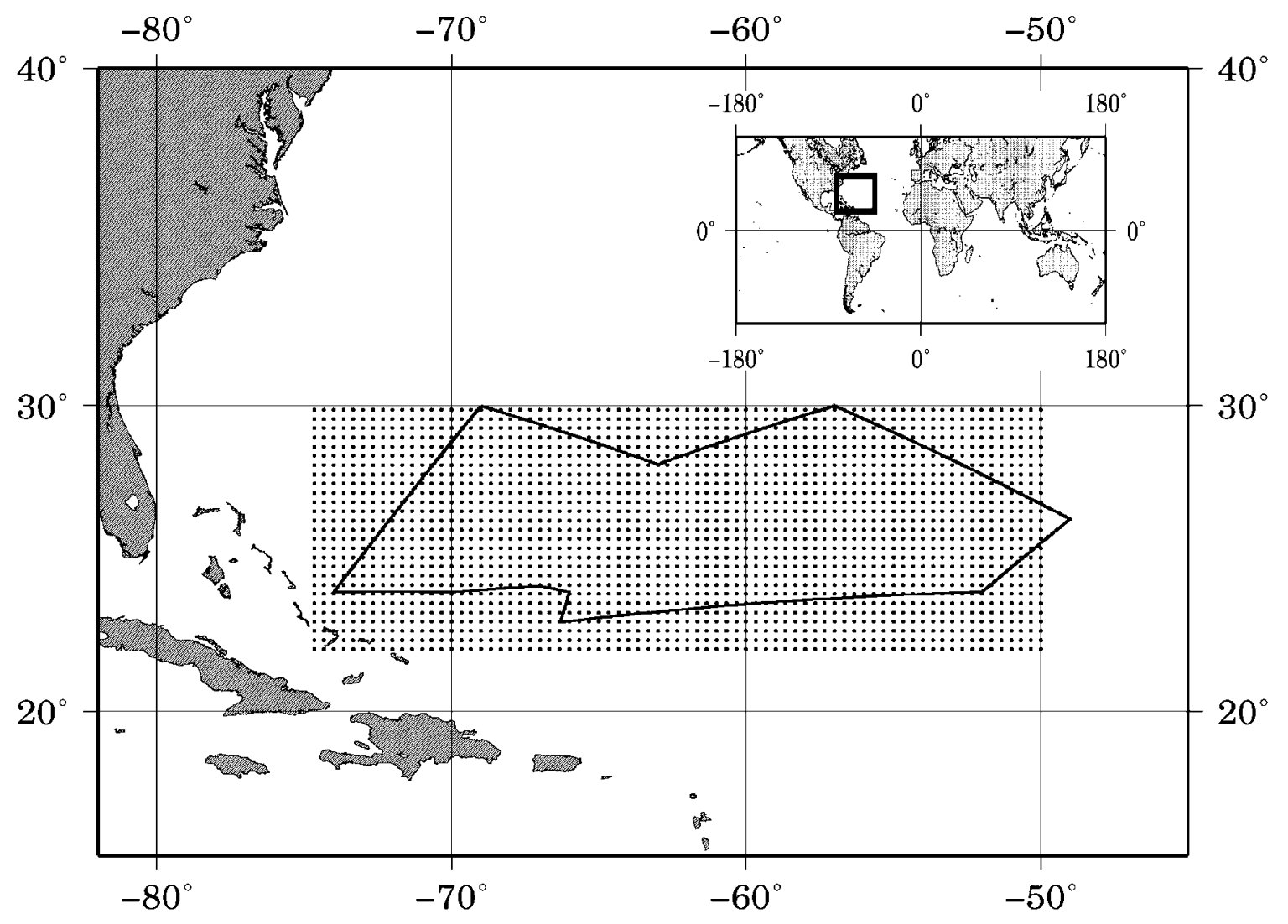


Figure 2
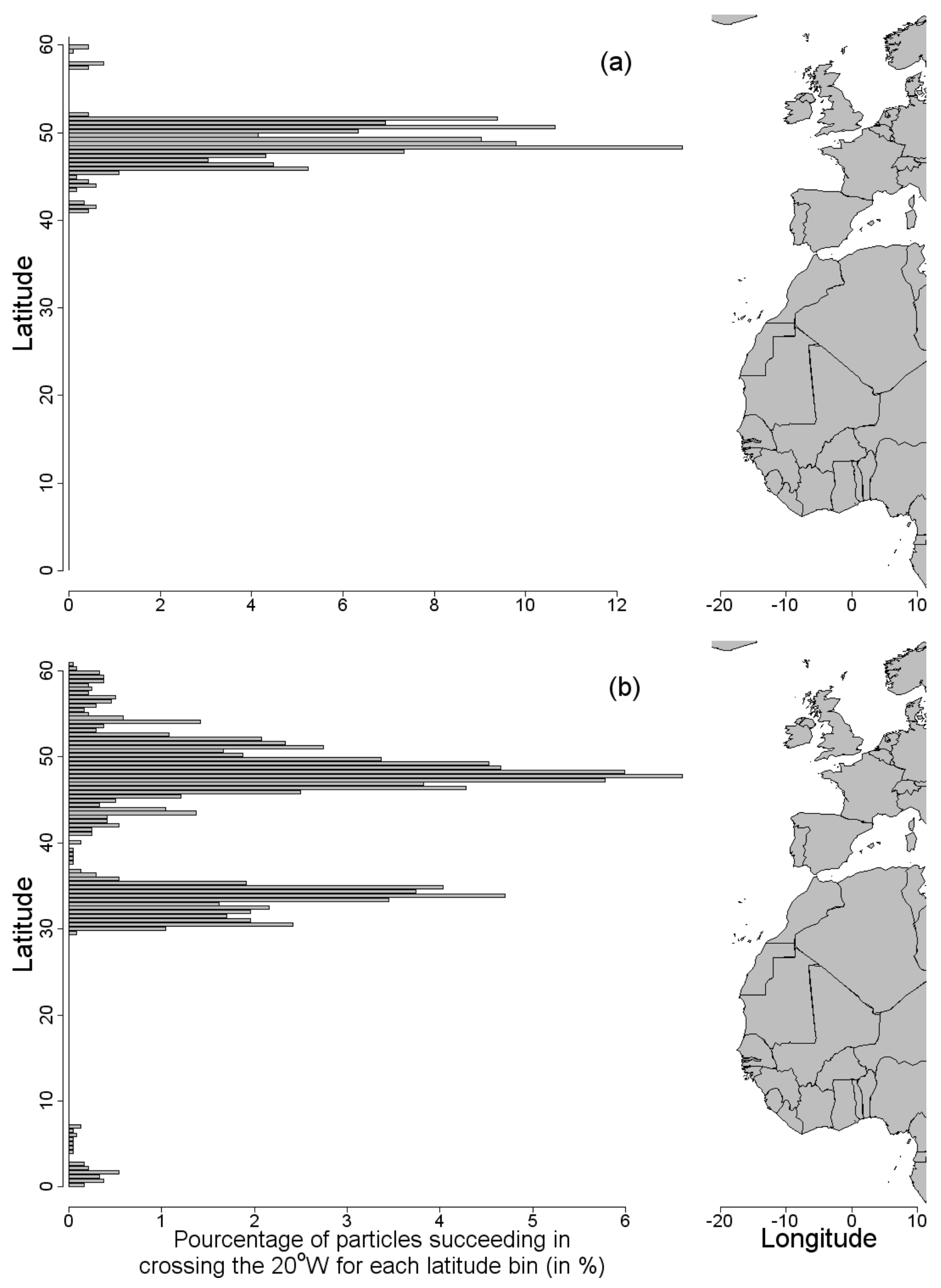
Figure 3

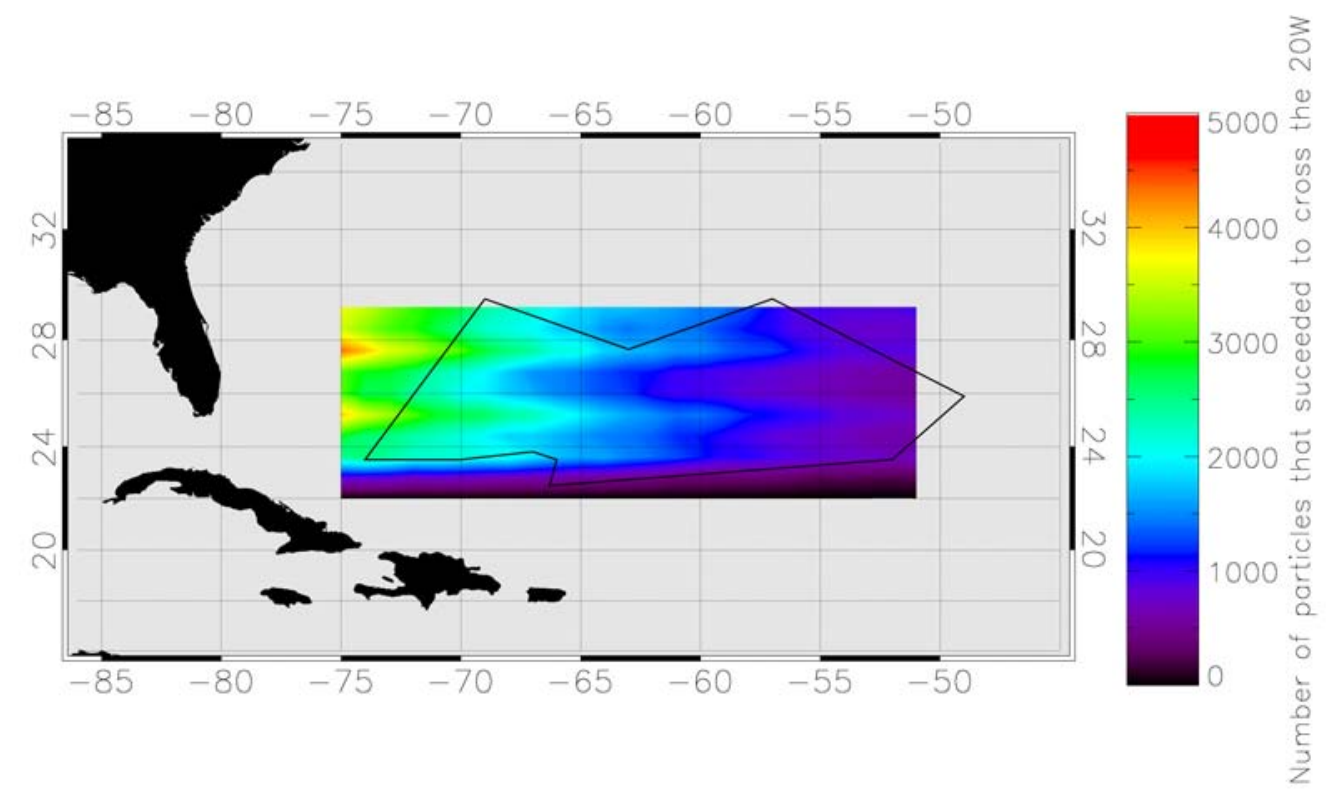


Figure 4
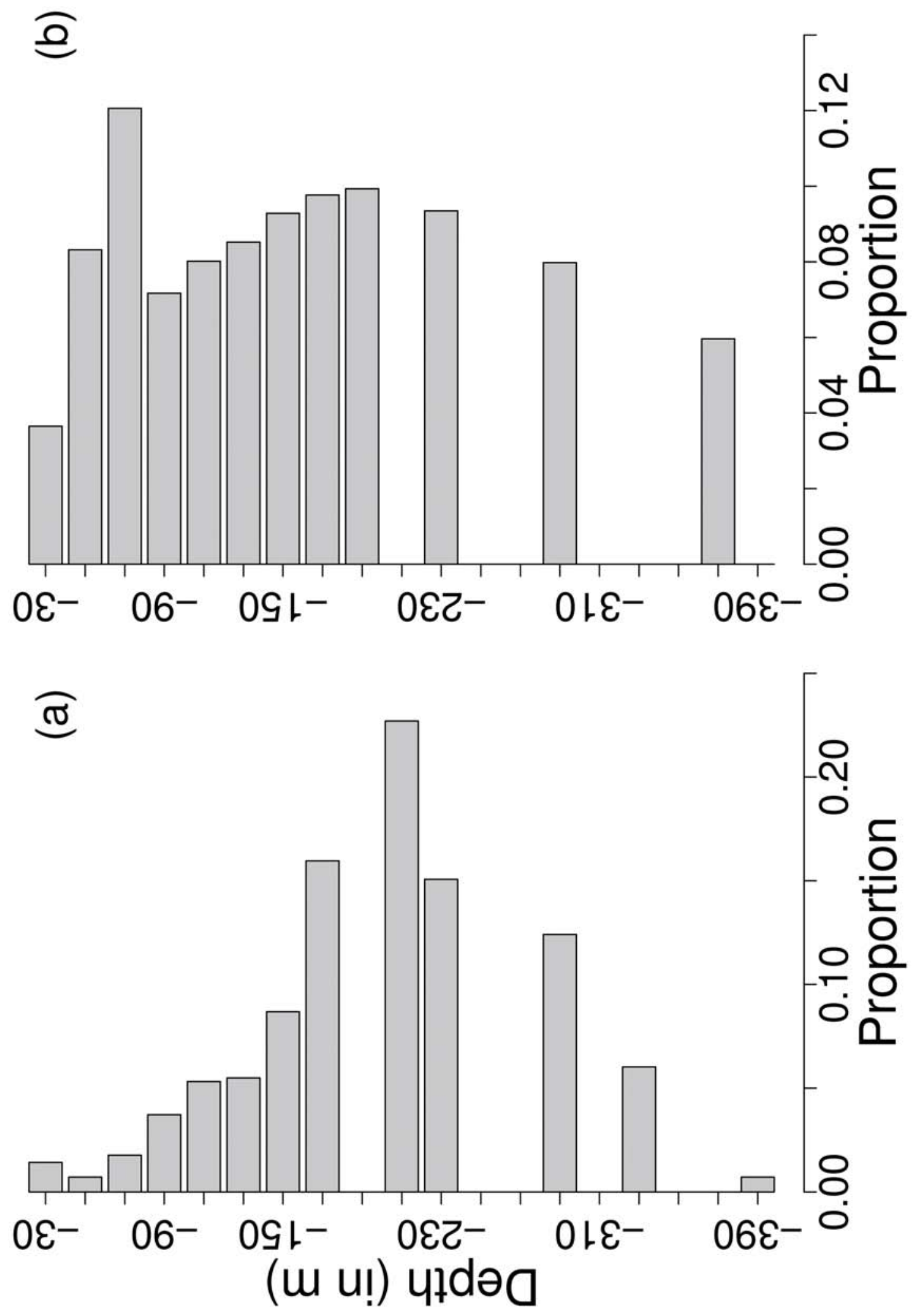
Figure 5

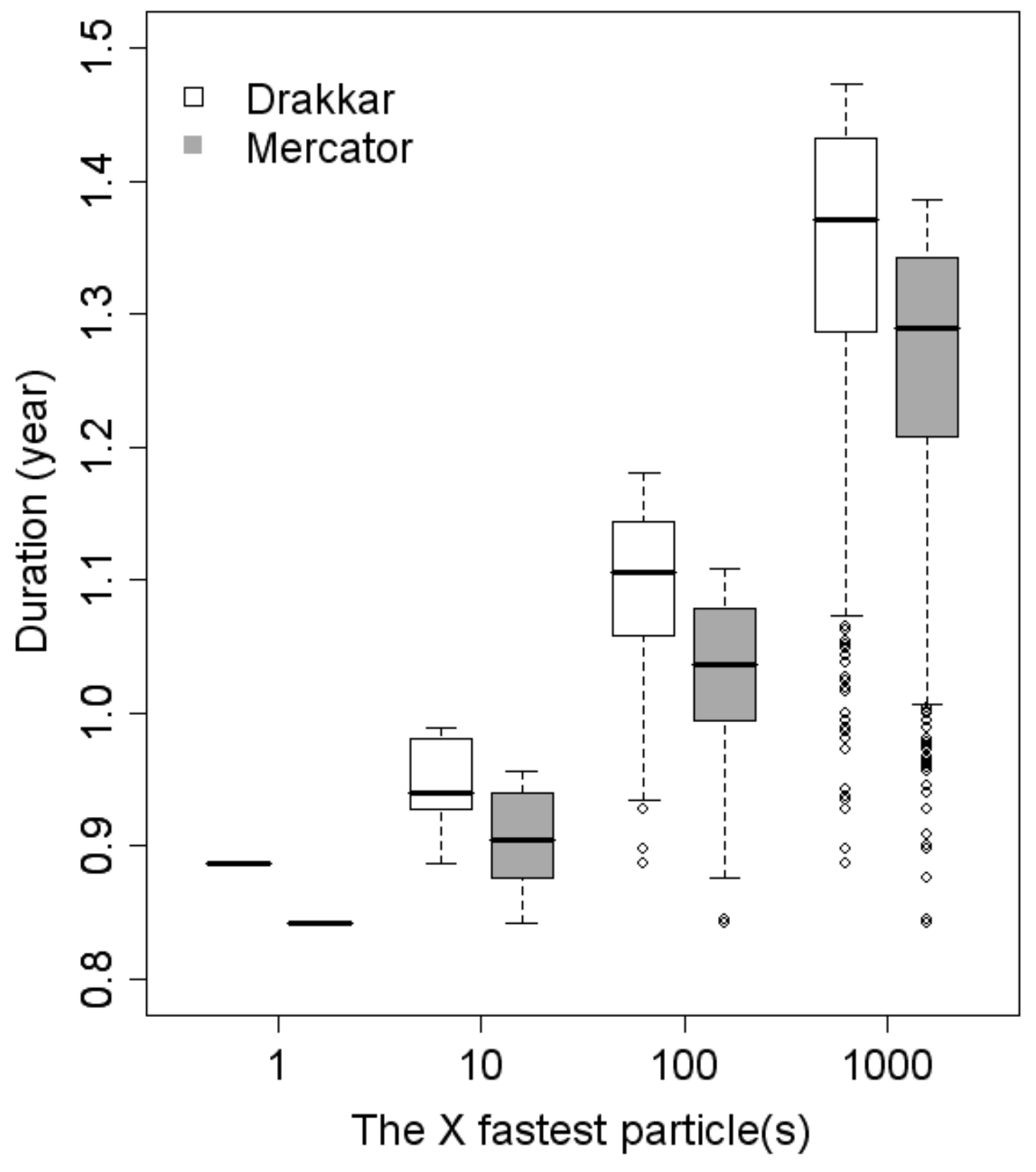


Figure 6

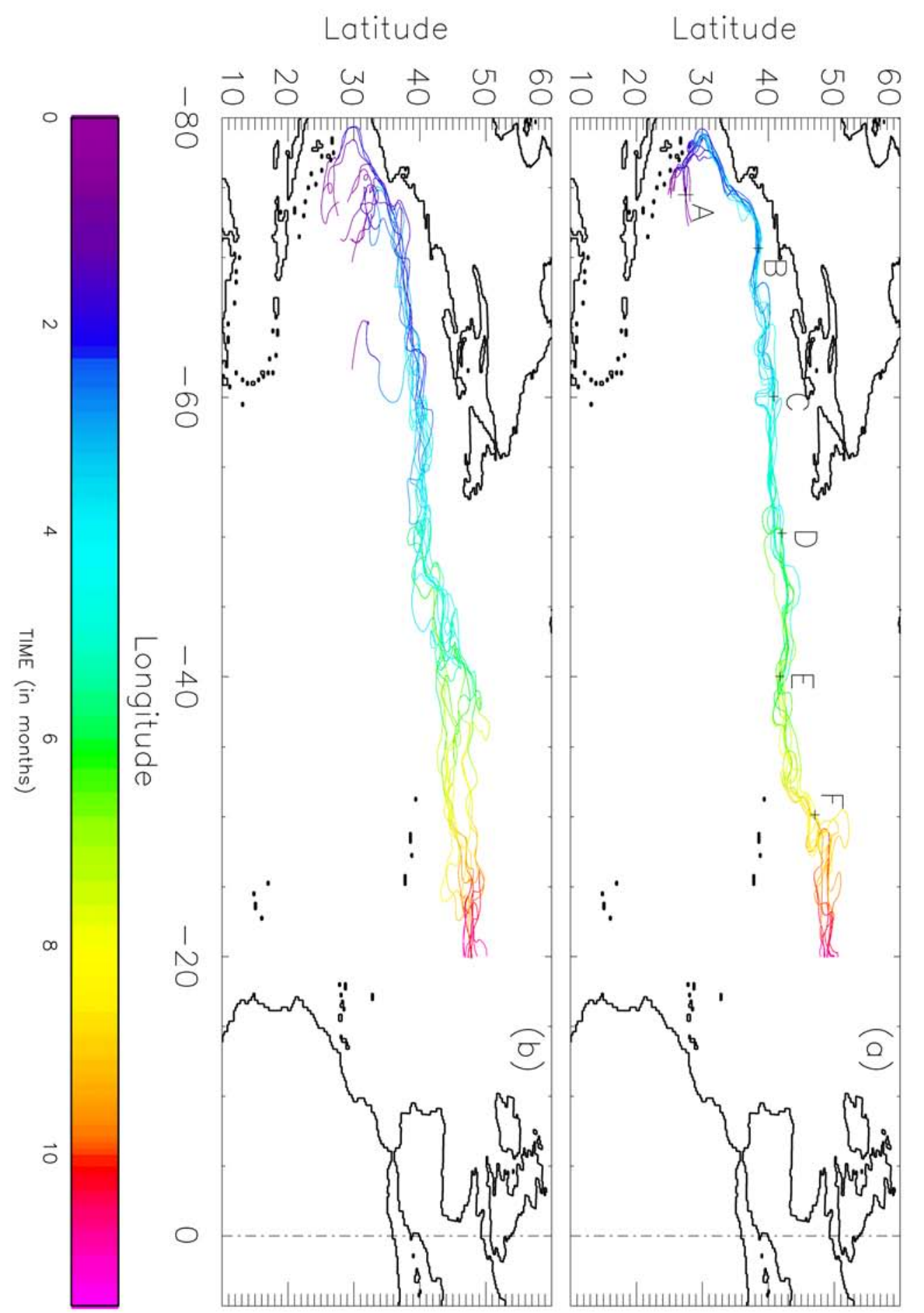


Figure 7
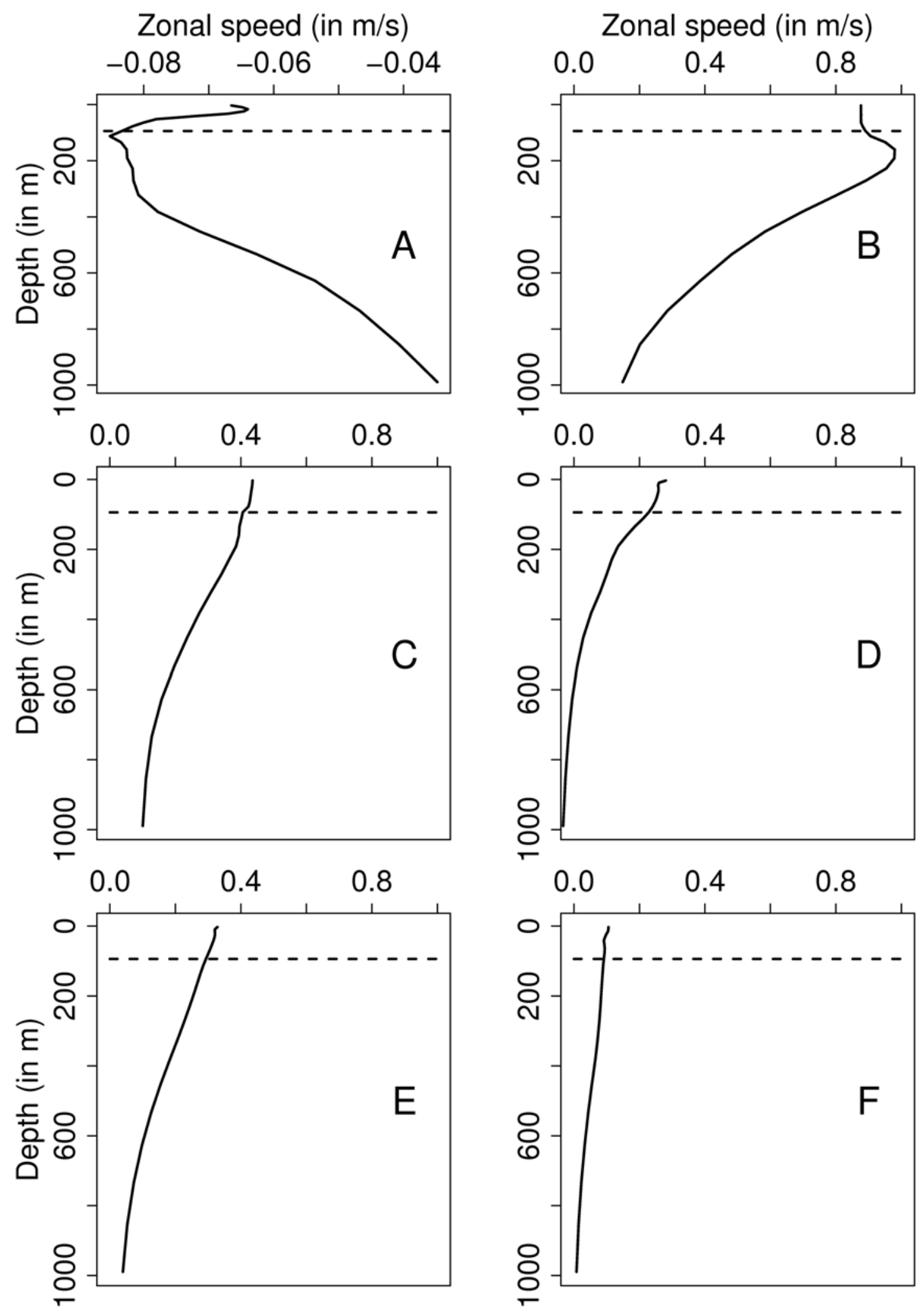
Figure 8

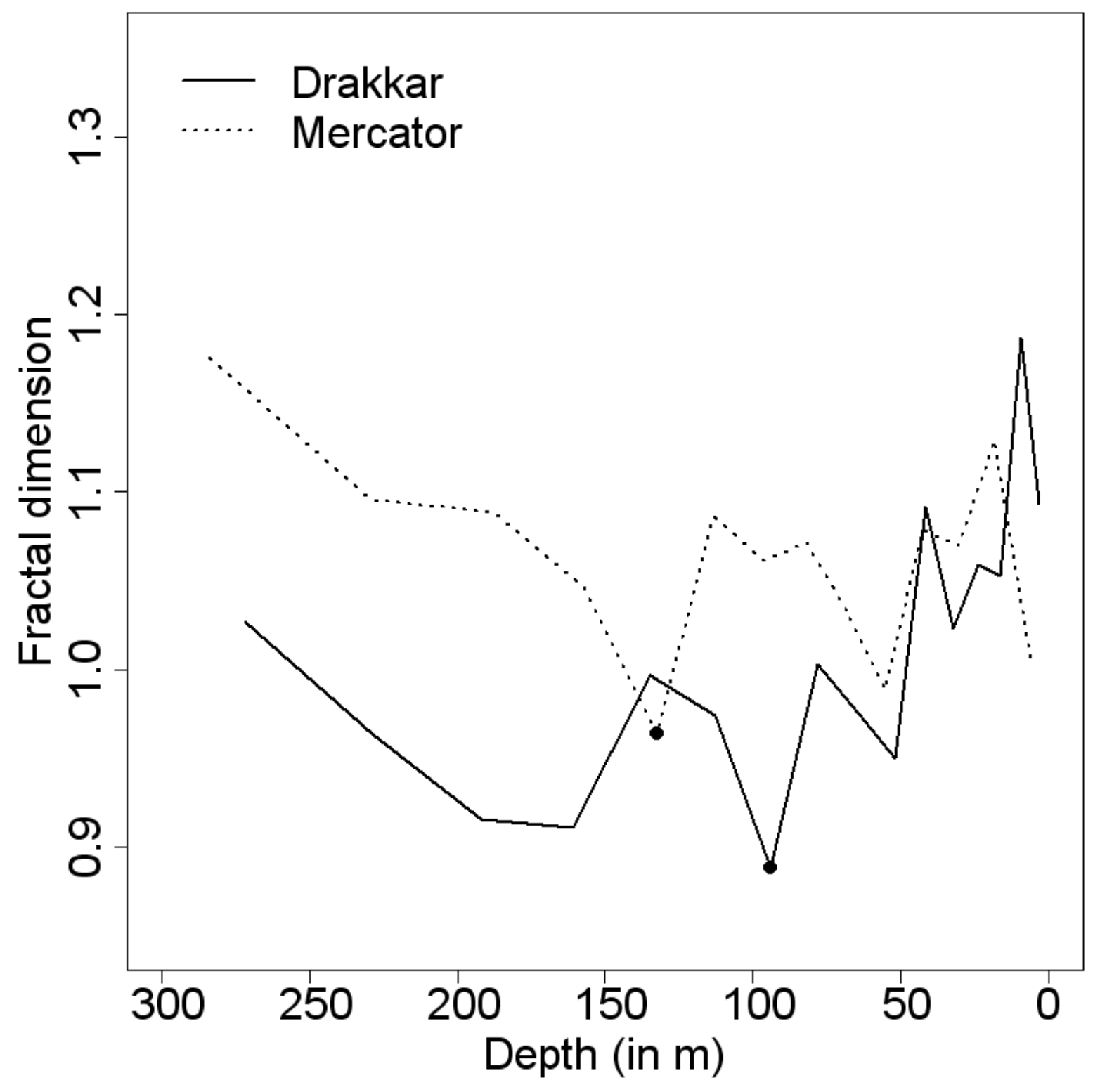

